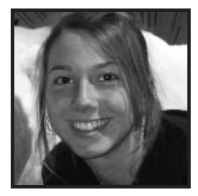

\title{
Developing Leadership Through the Cape Farewell Expedition
}

\author{
Amélie Tremblay-Martin, Chambly Academy
}

\section{ABSTRACT}

Amélie Tremblay-Martin addresses the issue of developing leadership through sharing and reflecting on a series of multiple activities that occurred on an expedition in the Norwegian Arctic. This expedition was a seen as a wonderful opportunity that challenged the author's leadership skills. By sharing her stories, she hopes that her experiences will resonate with others and help them to become better leaders themselves.

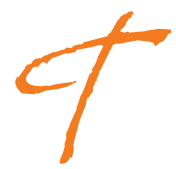

he year 2007 is one that will be remembered. On March 1st, the International Polar Year began. Cape Farewell, an organization engaged in raising climate change awareness, selected three Canadian, seven British and two German high school students to embark on the Noorderlicht, a 100year-old Dutch schooner, and sail to Svalbard, an island located in the Norwegian Arctic. Along with them were scientists, artists and media. Through a series of activities and experiments, they developed their leadership skills. I was one of three Canadians to take part in this expedition. Through my engagement in this experience, I have become a different person. I am more knowledgeable, aware, and selfexpressive and I have developed a stronger perspective on my environment. I have become a better leader.

Before setting sail, the other Cape Farewell students and I met some of the teenagers living on the island of Svalbard. We did a variety of activities with them as a team and in groups. One was a movement piece, an activity that was quite successful and pleasant. All the adolescents gave their opinions about climate change and 


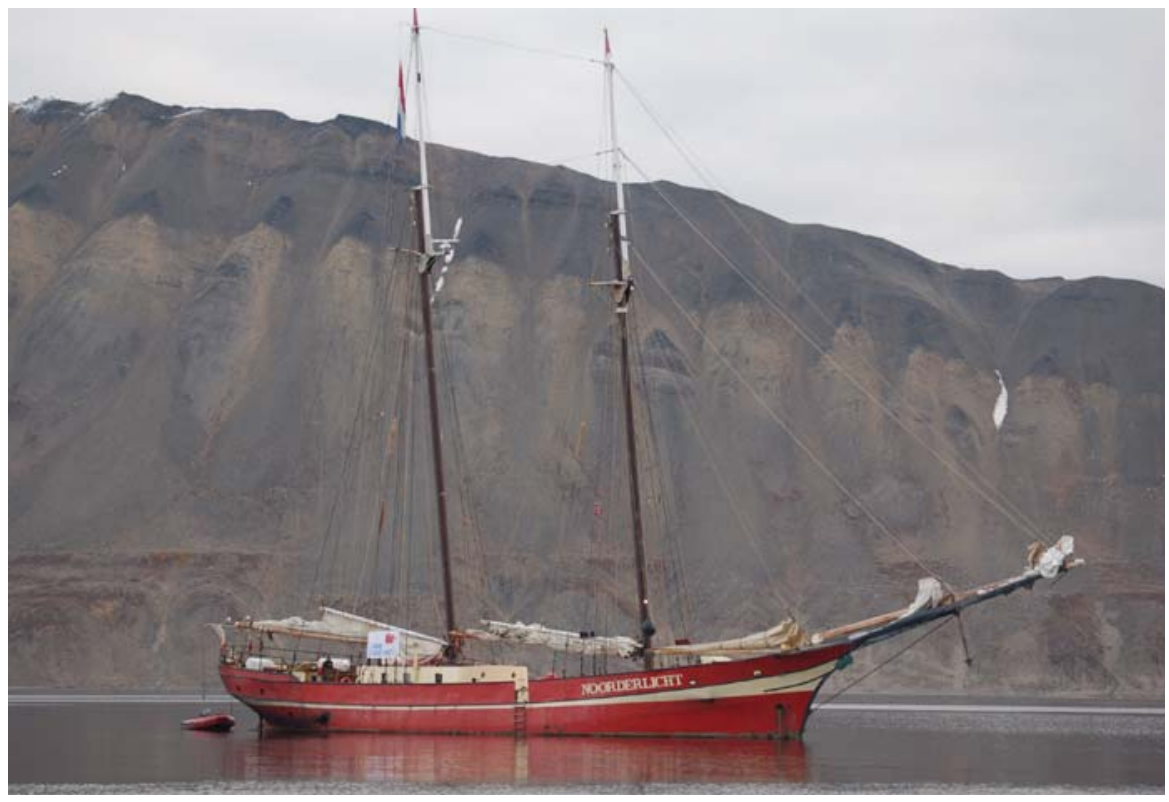

Fig. 1: Noorderlicht, 100-year-old Dutch schooner

how it is affecting them. Using the information everyone provided, we made a graceful abstract dance. To demonstrate that all the life on our planet is interdependent, my group created a domino effect. If one falls, we all fall. The adolescents in this activity were very shy so I took a stand. I asked different questions. Then I suggested several possible movements and everyone started sharing. Our movement dance reflected biodiversity, the variety of life such as plants, animals and microorganisms. It was presented in front of the student body that was in attendance for the activities.

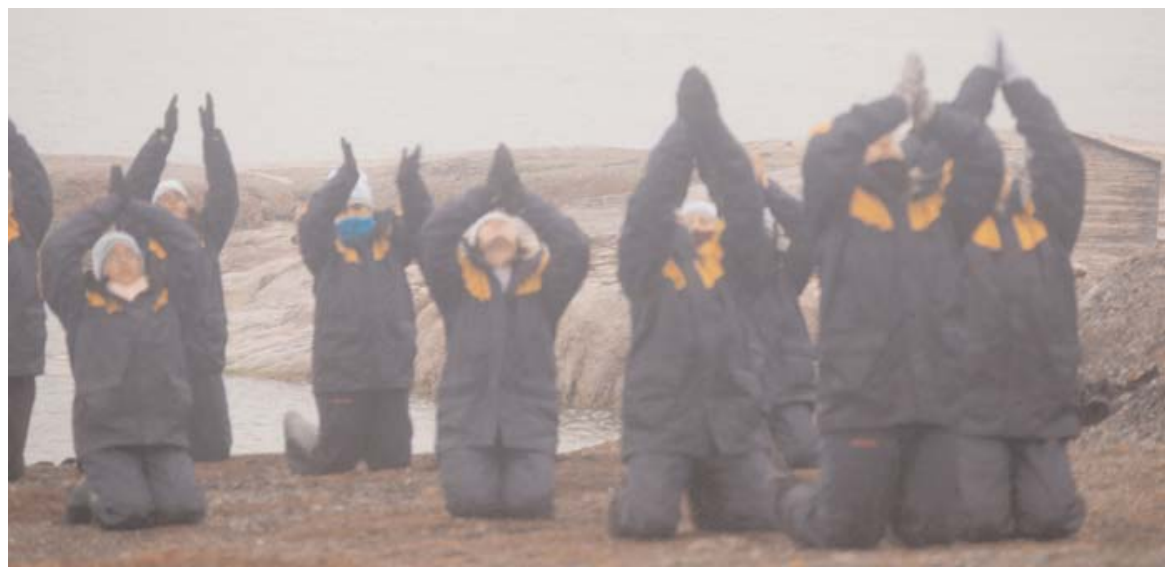

Fig. 2: Spiritual movement dance 
As a result I realized that my childhood experiences could come in handy in dealing with situations such as the ones I encountered in the expedition. I once lived in a small town so I know how it is when one is asked to take part in an activity. No one wants to share his or her views because it's frightening. Living in a small community puts pressure on an individual because everyone knows one another and if people begin acting a way that they normally wouldn't, their reputation may be at risk. "It takes 20 years to build a reputation and five minutes to ruin it," enlightened Warren Buffett $(2008$, p. 13). At the time, I was not aware of the leadership impact I had. My goal was to simply try to involve everyone. Soon after, I became more knowledgeable about my leadership skills.

On September $16^{\text {th }}$, the whole Cape Farewell team gathered and a visual artist began a discussion on the group art project we would be creating on a beach the following day. By interacting with her and sharing ideas, I increased the interest of my peers. The conversation led to many aspects of climate change. This example shows that being a leader is more about being brave enough to say what you want to get across and also to influence others, whether it is through words, science or art. It is someone who makes things happen. Could you be that someone?

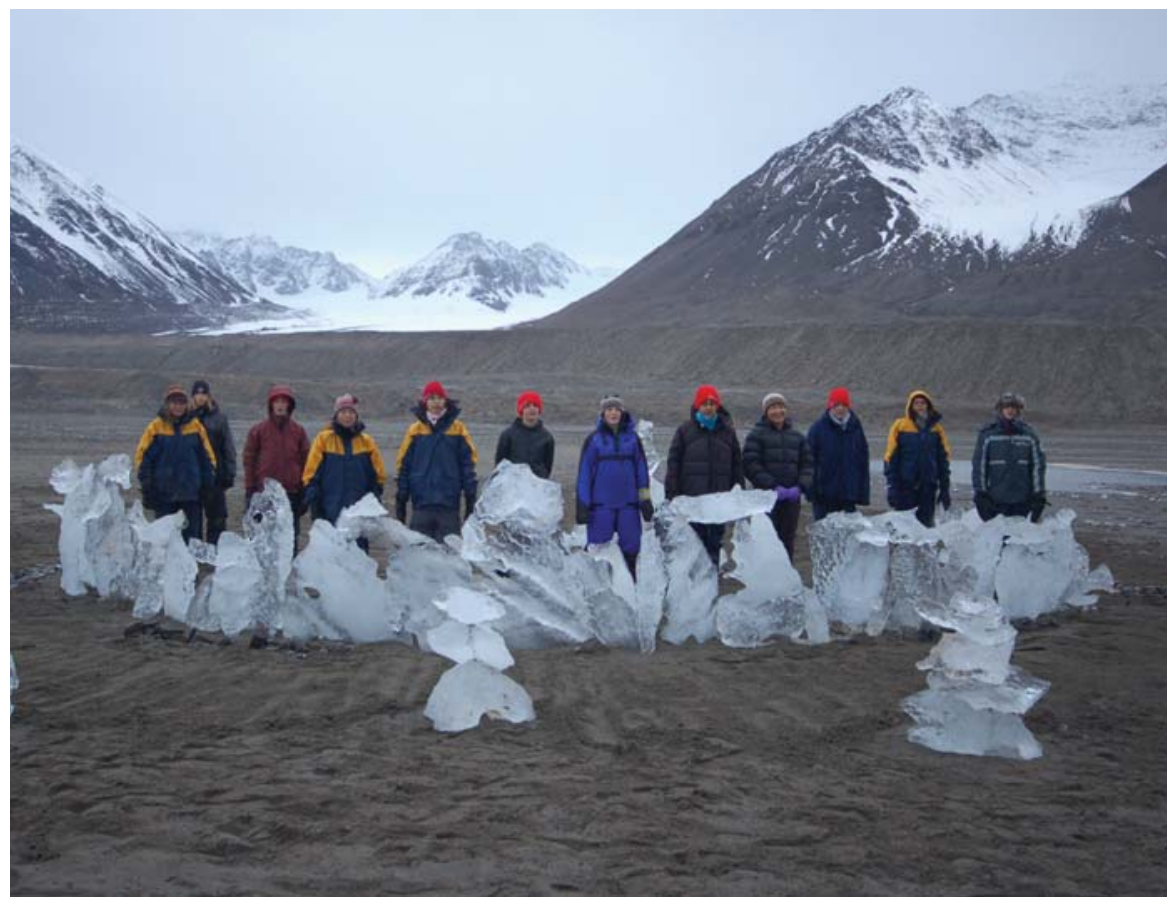

Fig. 3: Group art project 
I was always one to believe that self-expression had to be done through words. My art project taught me I was mistaken. Even though my talent with words is not great, it did not mean I did not have a voice for self-expression. I struggle a lot with words, simply because I want everything to sound good, so in the end I make it sound complicated and long. My speeches are like puzzles. The pieces are there, but they do not quite fit together unless I think long and hard ahead of time and try different arrangements. On this expedition I collected ideas and inspirations to make a stained-glass window. I used the sites that had a big impact on me. I attempted to represent them through shapes and colors of glass. Some of the things that inspired me were two polar bears, glaciers collapsing, plankton, the Noorderlicht and the sounds of the ocean, the breeze, and the birds. Also, the passageway around Blomstrand-o halvøya, a large piece of glacier that melted and created an island with a passageway in between, made me realize that with time things change, as do people.

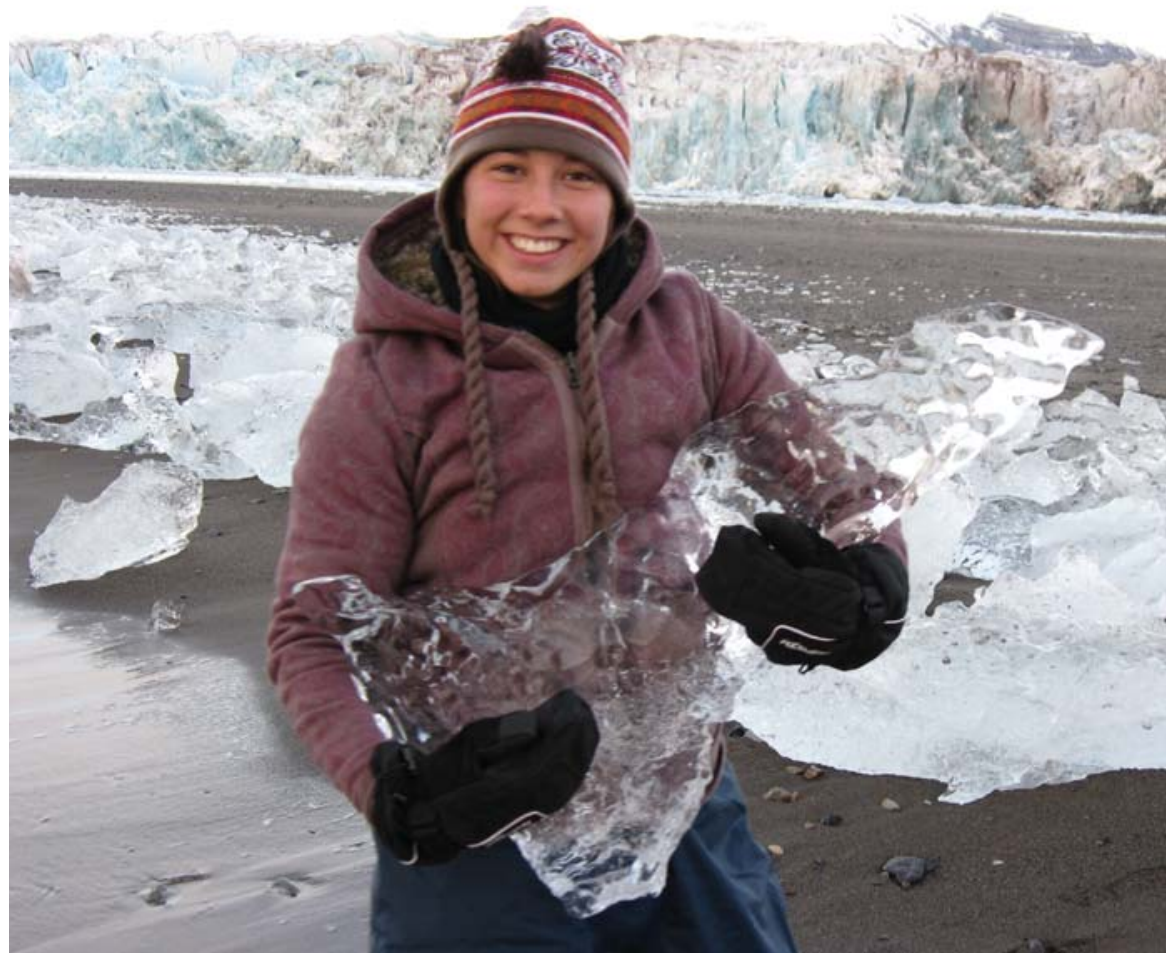

Fig. 4: Individual art project 
My science project was analyzing plankton: the smallest creatures in the ocean and at the bottom of the food chain. I had three partners for this project. We collected our data with a simple plankton net, salinity conductor and a few sampling bottles. We took four different depth samples at each of three sites. I learned to use equipment and how to do science out in the field. It is very important to make the data significant afterwards. With my partners, we analyzed the different samples using a microscope and documented our collected data. Then, we scheduled a time to draw conclusions. I have grown to realize that the most important part of the science experiment was the process. It was through the process that I developed new ways of approaching situations.

Unfortunately, not everyone has the opportunity to experience an expedition. There are different ways to look at leadership. Suggesting ideas and having a positive attitude is a start. There is also movement. Aboard the vessel, the whole Cape Farewell team had a dance. One was for a birthday and the other was for our final party. I encouraged some boys and girls to join the dancing; we played catchy songs such as YMCA and We Are Family. Being active is a leadership skill used for motivation and encouragement.

Furthermore, organizing an event or even something simple takes a lot of work. Aboard the ship, I decided to use my creativity and make cards for the crew. I knew I could not organize everything on my own. By admitting this, I was displaying maturity. I explained the situation to the other students and on the night of the party, they each created their own artistic and thoughtful art. I made cards for the crew, and another person made mini cards for the organizers and everyone got a giraffe with a thought describing his or her personality.

As a child, I always pictured the Arctic to be a big mass of white land. I realized that it is not. When I went to Svalbard, it was summer. The days were not as cold as I expected and there were approximately 20 to 22 hours of daylight. My real challenge was being a witness and accepting the changes that were occurring in our environment. An image to which I had held on tightly was quickly shattered. I have to adapt to these changes. This is easier said than done. My perspective about my environment is different. I am aware of the changes and I plan to pass on the message and take action. But I asked myself why would anyone who did not experience such an expedition take action? One of the quotes often used on the ship was, "We're all in this together." One cannot do everything alone. Previously, I mentioned a dance movement created by the Cape Farewell voyagers and the students from Svalbard. I spoke of the domino effect. This is a message that can be passed on. If one falls, we all fall. 
I have learned that I have always been a leader; it is a matter of applying the leadership skills and improving myself. This expedition showed me how. Cape Farewell gave me a voice, a voice I will use to be heard and to lead others through these tough times of climate change.

This experience has changed me.I am more knowledgeable, aware, and selfexpressive and I have developed a stronger commitment my environment, as well as to leadership. I believe that everyone has the capacities that a leader needs; it is just a matter of application and the circumstances of the situation. The year 2007 has drifted away and 2008, the International Glacier Year, has now begun. The years of my responsibility have begun.

\section{References}

Buffett, W. (2006). The Tao of Warren Buffett. New York: Scribner.

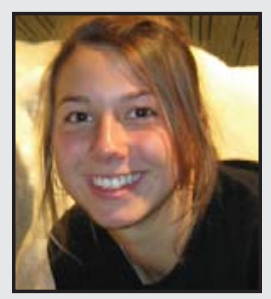

Amélie Tremblay-Martin is originally from Jonquière, Quebec. At the age of nine, she moved to northern British Columbia for the opportunity to learn English. After six years surrounded by mountains, she moved back to the Montreal region of Quebec. She plans to pursue her studies in science at Champlain College. 